\title{
Pengaruh Variabel Makro Ekonomi Terhadap Profitabilitas (ROA) Serta Dampaknya Pada Dividen Payout Ratio (DPR) Pada Perusahaan Sector Properti di Bursa Efek Indonesia (BEI)
}

\author{
Muhamad Nurhamdi ${ }^{1}$
}

1) Dosen Unversitas Pamulang,email: dosen02484@unpam.ac.id

\section{ARTICLES INFORMATION}

ABSTRACT

\section{JURNAL SEKURITAS}

(Saham, Ekonomi, Keuangan dan Investasi )

Vol.3, No. 3, Mei 2020 Halaman : $247-261$

(C) LPPM \& Prodi Manajemen UNVERSITAS PAMULANG

\section{ISSN (online) : 2581-2777} ISSN (print) : 2581-2696

\section{Keyword :}

Inflasi; Suku Bunga; Kurs Rupiah; Return on Asset; Dividen Payout Ratio

JEL. classification :

C33, G21, G24, N15, N25

\section{Contact Author :}

PRODI MANAJEMEN UNPAM

JL.Surya Kencana No.1

Pamulang Tangerang Selatan Banten

Telp. (021) 7412566, Fax (021) 7412491 Email :

sekuritas@unpam.ac.id
Penelitian ini bermaksud untuk mengetahui adanya pengaruh variable makro ekonomi pada profitabilitas serta dampaknya terhadap dividen payout ratio pada perseroan property and real estate diBursa Efek Indonesia tahun 20082017. Teknik Penelitian ini memakai metode kuantitatif descriptive serta dengan metode purposive sampling sebagai cara untuk mengambil sampel dan jumlah sample data yang diambil sebanyak 50 data, adapun metode analisis data menggunakan model regresi data panel model random effect untuk mencari pengaruh $\mathrm{X}$ terhadap $\mathrm{Y}$ dan dengan model Common Effect untuk mencari dampak $Y$ terhadap $Z$. Hasil Penelitian menunjukan bahwa secara parsial inflasi dan suku bunga tidak ada pengaruh yang signifikan pada ROA, namun kurs rupiah berefek signifkan dan positif pada profitablitas (ROA). Secara bersama-sama variabel inflasi, suku bunga dan kurs rupiah tidak ada pengaruh yang signifikan pada variebel $\mathrm{ROA}$, Serta variable retrun on asset(ROA) juga tidak terdapat pengaruh yang signifikan terhadap variable Dividen Payout Ratio

This Research is aims to determine the effect of macroeconomic variables on profitability and its impact on the dividend payout ratio of property and real estate company listed in Indonesia Stock Exchange in 2008-2017.

The Technique of this Study is quantitative descrivtive method, with the technique of taking samples using purposive sampling method and the amount of data taken as much as 50 data. The methode of data analysis is using regresion of data panel model of random effect to find the effect of $X$ against $Y$ and Common Effect Model tofind the Impactt of $Y$ on $Z$.

The result showed that partially inflation an intereset rate had no significant effect on retrun on asset, but exchange rate have positif and significant Impact on profitability (ROA) Simulaneously the variables of inflation, interest rate and exchange rate had no significant effect on return on Asset, Returtn asset also had no significant impact on dividen payout ratio. 


\section{A. PEndahuluan}

Sejarah telah mencatat berbagai krisis ekonomi yang terjadi di belahan dunia, seperti terjadinya Great Depression 1929 di Amerika Serikat yang menyebabkan jatuhnya pasar saham dan warga berbagai bank, serta krisis yang terjadi di tahun 2008 di Amerika Serikat, yaitu krisis cuti oleh kredit properti (Subprime Mortage). Di Indonesia, krisis besar pernah terjadi pada tahun 1998 sebagai pemindaian krisis Keuangan Asia pada tahun 1997 yang terjadi di beberapa negara Asia seperti Thailand dan Korea Selatan. Pada saat krisis, kondisi ekonomi makro Indonesia sangat buruk, salah satu indikator kondisi makro adalah tingginya tingkat inflasi dan melemahnya nilai tukar mata uang rupiah terhadap nilai tukar mata uang asing, salah satunya adalah nilai tukar rupiah terhadap dolar AS yang mencapai puncak tertinggi di level Rp. 16.800, -pada Juni 1998

Di era ini ekonomi makro sangat penting bagi suatu negara, insiden depresi besar yang melanda Amerika Serikat pada tahun 1929, menjadi titik awal untuk memikirkan kembali tentang pandangan ekonomi klasik yang diadopsi selama masa ini. Dalam model klasik disebutkan bahwa pembahasannya tidak akan lama. Tawaran Kelebihan Tenaga Kerja akan mengakibatkan upah turun sehingga tingkat keseimbangan baru akan muncul. Analisis peluang kerja diselesaikan oleh teori permintaan dan penawaran, tetapi tampaknya analisis klasik tidak mampu mengatasi depresi besar yang melanda Amerika Serikat yang berjalan hingga 10 tahun. Karena itu, kegagalan teori klasik dalam menyikapi masalah pengangguran di Amerika Serikat menjadi tonggak sejarah dalam ekonomi makro (Tri Kurniawan dan Anton Pracoyo, 2007: 7).

Dalam ekonomi makro ada beberapa variabel yang menarik di antaranya adalah nilai tukar rupiah, tingkat inflasi, suku bunga dan lainnya. Variabel-variabel ini sangat penting dan perlu diperhatikan oleh berbagai pemerintah, komunitas, dan perusahaan. Karena kondisi ekonomi makro tidak jarang kita memenuhi kondisi sebagai bahan pertimbangan untuk menentukan strategi perusahaan seperti strategi penjualan, strategi manajemen risiko atau kebijakan dalam berinvestasi. Pencapaian keuntungan bagi perusahaan adalah hal mutlak yang harus dipenuhi untuk keberlanjutan perusahaan, di tengah kondisi ekonomi saat ini tentunya perusahaan memiliki tantangan yang sangat besar, khususnya perusahaan-perusahaan yang bergerak dalam industri property dan perumahan yang terregister di Indonesia stock Exchange.

Pada dekade ini perusahaan properti dan real estate berkembang sangat pesat. Ini bisa dilihat dari meningkatnya aset perusahaan yang semakin meningkat dari tahun ke tahun, tentunya hal tersebut merupakan kondisi yang baik bila dilihat dari segi kepemilikan asset yang semakin meningkat, akan tetapi di tengah melemahnya kondisi ekonomi saat ini perusahaan properti dan real estate ini cukup mengalami tekanan, hal tersebut dapat dilihat dari survei yang dilakukan oleh Bank Indonesia pada tahun 2017. Adapun gambaran survey tersebut penulis sajikan dalam grafik berikut ini: 


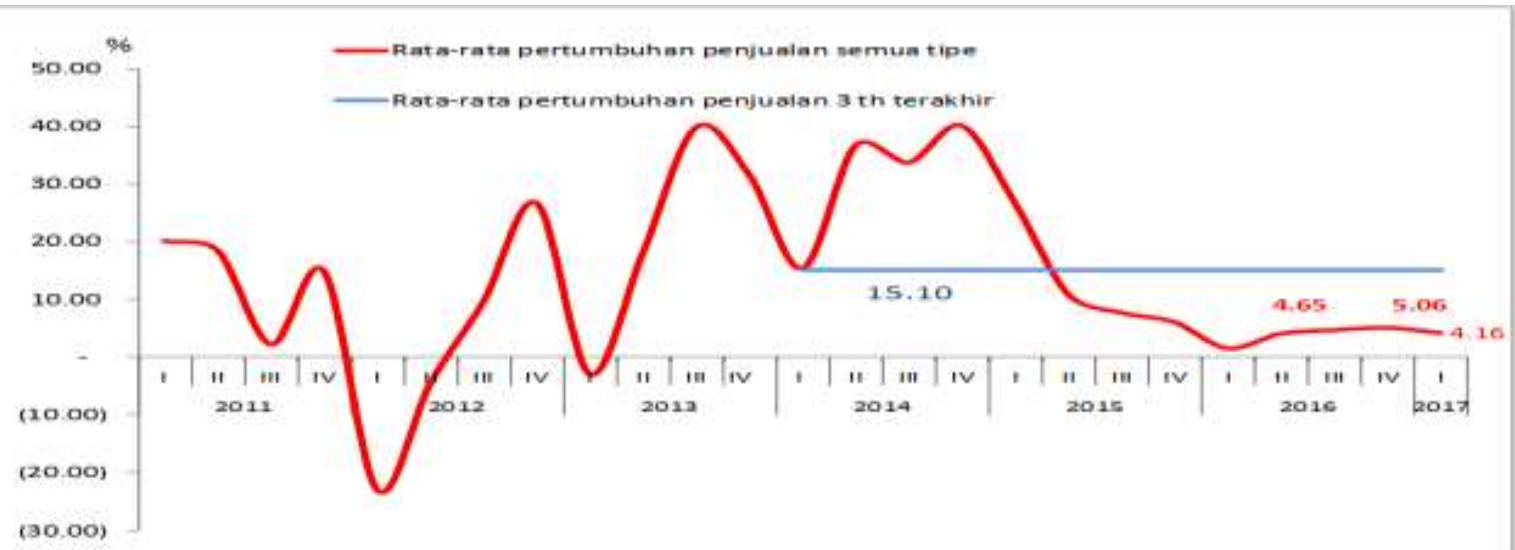

Sumber : Bank Indonesia

Gambar 1.1 Grafik Pertumbuhan Penjualan Residensial

Dalam survey tersebut dapat dilihat bahwa pertumbuhan penjualan properti residensial tumbuh lebih melambat dari kuartal sebelumnya dari 5,06\% menjadi $4,16 \%$, bahkan pertumbuhan penjualan sempat mengalami negative pada kuartal ke empat di tahun 2011. Selain melambatnya penjualan product properti, dari segi keuangan perusahaan property juga mengalami sedikit penurunan kinerja keuangan, hal tersebut bisa dilihat dari tingkat pengembalian investasi pada asset atau Return on Asset, dimana penulis menyajikannya dalam data berikut ini:

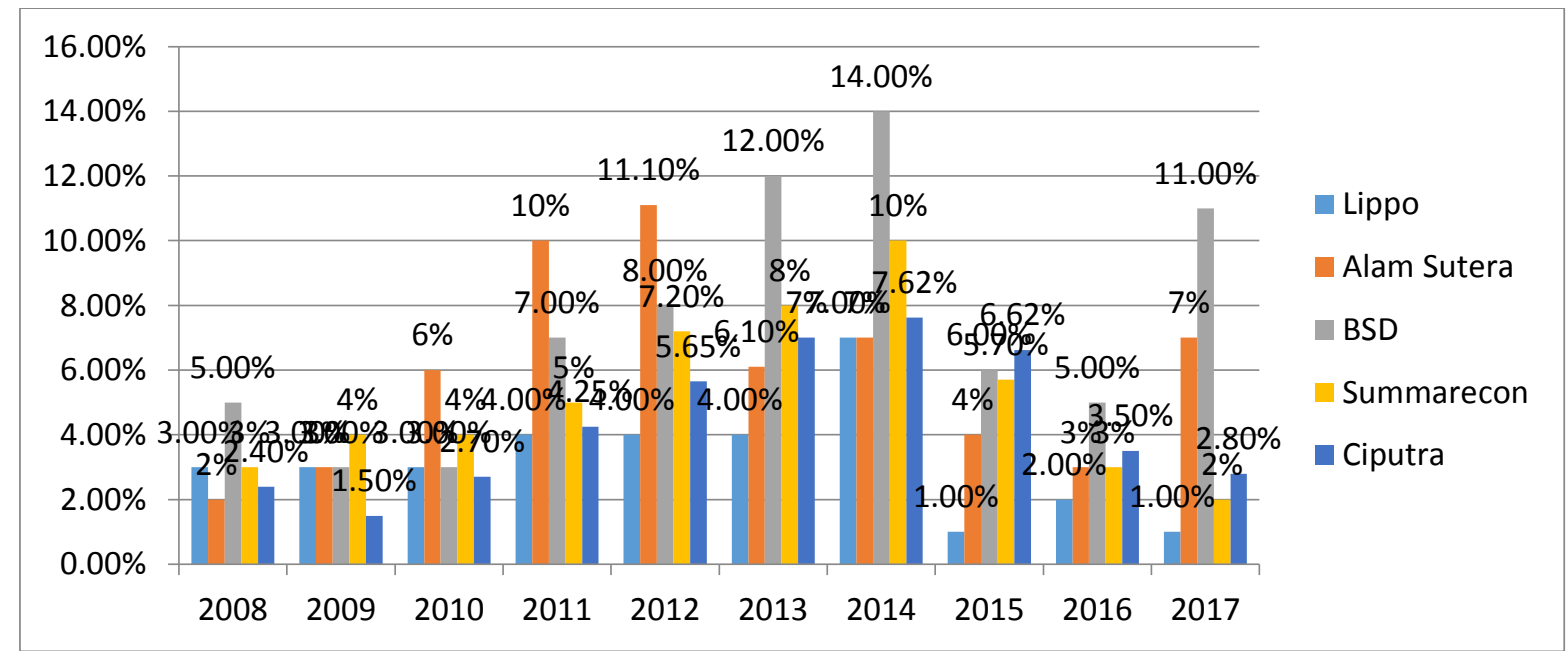

Sumber: financial Report

Gambar1.2 Chart Pertumbuhan ROA

Dari grafik tersebut bisa dilihat terjadinya penurunan tingkat ROA tiap perusahaan yang secara umum dari tahun 2014-2017, dimana para emiten yang cukup besar seperti Lippo, Alam Sutera, BSD, Summarecon dan Ciputra mengalami penurunan tingkat ROA dari tahun ke tahun. Oleh sebab itu baik pemilik perusahaan ataupun investor harus melihat kondisi tersebut guna mengantisipasi hal yang tidak diinginkan, selain dari pada itu kondisi makro ekonomi bisa jadi menimbulkan tekanan terhadap kondisi keuangan perusahaan, adapun rangkuman makro ekonomi perusahaan penulis sajikan dalam grafik berikut ini: 


\section{Variabel Makro Ekonomi Indonesia}

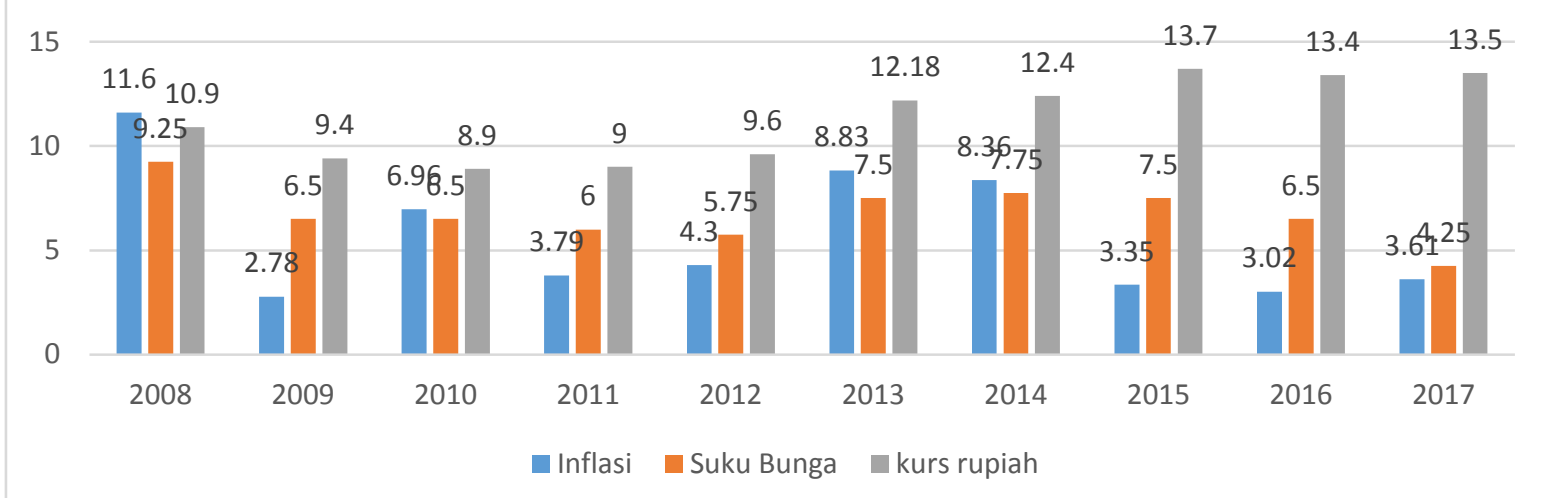

Sumber : Badan Pusat Statistik, Bank Indonesia (data diolah kembali)

Gambar 1.3 Laju Inflasi, suku bunga, kurs rupiah tahun 2008 - 2017

Berdasarkan data diatas inflasi cukup tinggi terjadi pada tahun 2008, 2013 dan 2014, adapun tingkat SBI menurun dari tahun ketahun, penurunan suku bunga tentunya secar perlahan akan berakibat pada menurunnya tingkat bunga KPR, hal yang menarik adalah kurs rupiah terhadap dollar semakin melebar dari tahun ke tahun tentunya hal ini tidak terlalu baik bagi perusahan karena dengan kurs yang tinggi menyebabkan biaya material yang diimport, hutang perusahaan dalam US Dollar mengalami pembengkakan yang mengakibatkan kinerja keuangan tertekan.

Keadaan makro ekonomi yang kurang baik tentunya di kawatirkan akan berpengaruh pada perusahaan, salah satunya terjadinya penurunan tingkat profitabilitas dan akan memberikan dampak pada penurunan kemampuan perusahaan dalam memberikan dividen kepada pemegang saham. Dividen merupakan suatu acuan bagi investor apakah akan berinvestasi pada perusahaan tersebut, karena investor menginginkan keuntungan. Dividen yang dihasilkan oleh pemegang saham tentunnya diperoleh apabila perusahaan memiliki profit atau memiliki tingkat profitabilotas yang baik. Oleh sebab itu profitabilitas perusahaan tentunya harus dipertahankan agar perusahaan mampu membagikan dividen kepada pemegang saham, namun berdasarkan gambar 1.1 tingkat ROA perusahaan semakin menurun, apakah hal tersebut akan berdampak pada dividen atau tidak, perlu dilakukan kajian. Oleh karena itu perlu dilakukan kajian mendalam untuk mengetahui hubungan kondisi makro ekonomi yang ada terhadap kondisi profitabilitas pada perusahan, selain itu kita juga dapat mendalami apakah kondisi profitabilitas pada persuahaan memiliki efek atau dampak terhadap dividen.

Berdasarkan data diatas yang sudah penulis paparkan terkait kondisi makro dan tingkat profitabiltas pada perusahaan, penulis ingin melakukan kajian lebih mendalam tentang keterkaitan dan pengaruh antar variable tersebut, dimana inflasi, suku bunga dan kurs rupiah merupakan variable terpilih dari makro ekonomi yang akan penulis gunakan dalam penelitian ini untuk dicari pengaruhnya terhadap profitabilitas dimana variable return aset menjadi salah satu variabelnya, kemudian yang merupakan salah satu dari Rasio Profitabilias, selain itu dalam penelitian ini tingkat profitabilitas juga perlu diteliti apakah memiliki dampak pada dividen. Dalam hal ini unit analisis yang akan diteliti adalah perusahaan-perusahaan property, Karena berdasarkan pemaparan diatas tingkat profitabilitas dalam hal ini ROA mengalami penurunan, adapaun perusahaan-perusahaan 
tersebut adalah PT. Lippo Karawaci Tbk, PT. Bumi Serpong Damai Tbk, PT. Summarecon Tbk, PT. Alam Sutera Reality Tbk dan PT. Ciputra Development Tbk.

Untuk memperkuat alasan penulis tertarik dalam membuat penelitian adalah, Pertama adanya suatu penelitian pendahuluan yang dilakukan oleh Amelia Nurul Hidayati (2014) dengan judul yang diteliti adalah "Pengaruh inflasi, BI Rate, dan Kurs terhadap profitabilitas pada bank syariah Indonesia", kemudia penelitan kedua oleh Amirus Shodiq berjudul "Pengaruh Variabel Makro Ekonomi terhadap profitabilitas bank syariah di Indonesia periode 2009-2014"(Sodiq, 2016), Hal yang menarik dari kedua penelitian pendahuluan tersebut adalah untuk penelitan yang dilakukan Amelia Nurul Hidayati hasil penelitian didapatkan bahwa profitabilitas perusahaan dipengaruhi secara signifikan oleh inflasi dan kurs, namun hasil tersebut sangat berbeda dengan apa yang temukan oleh Amirus Shodiq dimana dalam penelitiannya diiketahui profitabilitas tidak dipengaruhi secara signifikan oleh. Tentunya diantara kedua riset tersebut terjadi ketidak konsistenan hasil yang diperoleh, serta unit analisis yang diteliti adalah perusahaan perbankan. Oleh sebab itu perlu adanya penelitian kembali pada perusahaan yang berbeda core bisnisnya sehingga penelitan ini mampu memperkaya khasanah ilmu pengetahun serta memberikan informasi yang terbaru. Maka dari itu penulis tertarik dan memutuskan untuk melakukan penelitian tentang hubungannya antar Makro ekonomi dan Profitabilitas dimana ROA sebagai indikatornya serta Kebiakan dividen dimana Dividen Payout Ratio sebagai indikatornya dengan judul penelitian "Pengaruh variable makro ekonomi terhadap profitabilitas serta dampaknya pada dividen payout ratio pada perusahaan sector property dan real estate yang terdaftar di Bursa Efek Indonesia periode 2008-2017"

Berdasarkan pemaparan dan kajian pendahuluan serta identifikasi pemasalahan diatas penulis menetapkan rumusan permasalahan:

a. Bagaimana pengaruh inflasi terhadap profitabilitas (ROA) perseroan sub-sektor property and real estate diBursa Efek Indonesia?

b. Bagaimana pengaruh suku bunga terhadap profitabilitas (ROA) perseroan sub-sektor property and real estate diBursa Efek Indonesia?

c. Bagaimana pengaruh kurs rupiah pada profitabilitas (ROA) perseroan property and real estate diBursa Efek Indonesia?

d. Bagaimana pengaruh inflasi, suku bunga, kurs rupiah pada profitabilitas (ROA) secara bersama-sama pada persoran sub-sektor property and real estate yang ada diBursa Efek Indonesia?

e. Bagaimana dampak profitabilitas (ROA) terhadap Dividen payout ratio (DPR) pada perseroan sub-sektor property and real estae diBursa efek Indonesia?

\section{B. KAJIAN LITERATUR}

1. Manajemen Keuangan

Definisi dari manajemen keuangan adalah aktivitas dari pemilik dan manajemen dalam mendapatkan Capital Resource yang paling murah, lalu menggunaknnya seefektif, seeffisien serta seproduktif-produktifnya untuk memperoleh keuntungan. (Darsono \& Ashari, 2009)

2. Inflasi

Pengertian dari inflasi dalam pandangan (Kunawangsih \& Pracoyo, 2007) bahwa inflasi merupakan sebagai kenaikan harga secara keseluruhan yang berlangsung secara terus menerus. Adapun rumus inflasi adalah sebagai berikut:

$$
\operatorname{lnfl}=\frac{P i t-P i t_{-} 1}{P i t} \times 100 \%
$$


3. Suku Bunga

Suku bunga merupakan suku bunga kebijakan yang mencerminkan sikap atau stance kebijakan moneter yang diterapkan oleh Bank Indonesia dan diumumkan kepada public.(Bank Indonesia, 2016)

4. Kurs Rupiah Menurut (Sadono, 2004) kurs adalah nilai seunit valuta (mata uang) asing apabila ditukarkan dengan mata uang dalam negeri.

5. Tingkat pengembalian Assets / Return on Assets

Return on Assets adalah kesanggupan perseroan dalam mencapai keuntungan/profit dengan menggunakan semua Aktiva yang ada pada perusahaan (Sutrisno, 2013). Adapun rumus ROA adalah sebagai berikut:

$$
\mathrm{ROA}=\frac{E A T}{\text { Total Aktiva }} \times 100 \%
$$

\section{Dividen Payout Ratio}

Menurut hanafi dalam Pratama Mahardi (2015) Dividen payout ratio merupakan perbandingan kas dividen dengan laba setelah pajak. Semakin besar dividen payout rationya maka akan semakin besar jumlah dividen yang dibagikan. Adapun rumus dividen payout ratio adalah sebagai berikut:

$$
\text { DPR }=\frac{\text { Dividen per Lembar saham }}{\text { Laba per lembar saham }}
$$

\section{METODOLOGI PENELITIAN}

Metode penelitian dalan penelitan ini adalah Metode kuantitatif deskriftif dimana data yang diolah berupa data yang berwujud angka(Riduwan, 2014). adapun penentuan sample dalam penelitan ini berdasarkan metode purposive sampling dimana sample yang diambil berdasarkan kriteria tertentu yang diambil oleh penulis, bentuk data yang digunakan merupakan data panel, sementara penulis mengambil data berupa Secondari data yang diperoleh dari studi kepustakaan, internet dan laporan keuangan perusahaan yang tersedia dalam website masing-masing perusahaan. adapun sample perusahaan yang ditetapkan oleh penulis terdiri dari 5 perusahaan diantaranya adalah Lippo karawaci, BSD, Ciputra Development, Alam Sutera dan Summarecon.

Penulis menggunakan metode regresi data panel untuk menganalisa data pada penelitian ini, adapun software yang digunakan adalah software Eviews 9 sebagai alat bantu dalam penelitian, selain dari pada itu tahapan analisis data dalam penelitian ini diawali dengan beberapa model pungujian diantaranya adalah menggunakan pengujian Common, Fixed and Random Effect.Setelah itu melakukan pemilihan model yang tepat, diantaranya adalah dengan melakukan Chow Test, pengujian tersebut dilakukan untuk memilik model yang terbaik diantara model efek tetap dengan model common efek, setelah uji tersebut dilakukan langkah selanjutnya dengan melakukan uji kedua dengan menggunakan uji hausman, pengujian ini dilakukan guna mendapatkan moel yang terbaik diantara model efek tetap dan model random. Ditahap ketiga dalam metode pemilihan model dilakukan uji Lagrange Multiplier, pada pengujian ini dilakukan agar didapatkan model yang paling baik diantara dua model yaitu model common dan random efek. 
Langkah selanjutnya dalam proses analisis data ini adalah dengan melakukan Classic Assumption test. Secara teoritis pengujian pada Assumption Clasic itu terdiri dari beberapa pengujian seperti multicolinearity test, autocorrelation, normality test, heteroskedastisitty test, namun dalam pada kasus yang mengunakan jenis data panel dan pendekatan regresinya berupa ordinary least square (OLS) maka dari itu pengujian ini hanya menggunakan uji Multikolinearitas dan Heteroskedastisitas (Tri Basuki \& Yuliadi, 2015).Setelah pengujian asumsi klasik tahap selanjutnya adalah melakukan uji regresi data panel dan uji hipotesis.

\section{HASIL DAN PEMBAHASAN}

\section{Pengujian Kesesuaian model}

a. Chow test

Inflasi, Suku bunga dan Kurs rupiah terhadap variable Return on Assets

Tabel 4.1 Chow Test $X$ terhadap $Y$

Redundant Fixed Effects Tests

Equation: Untitled

Test cross-section fixed effects

\begin{tabular}{lrrr}
\hline \hline Effects Test & Statistic & d.f. & Prob. \\
\hline \hline Cross-section F & 4.244161 & $(4,42)$ & 0.0056 \\
Cross-section Chi-square & 16.973594 & 4 & 0.0020 \\
\hline \hline
\end{tabular}

Sumber: output eviews

Berdasarkan data diatas dapat diketahu bahwa model efek tetap lebih baik dari model common efek, hal tersebut bisa dilihat dari nilai Prob cross-section $F$ sebesar $0.0056<0.05$ dimana $\mathrm{H} 0$ tertolak dan $\mathrm{H} 1$ diterima

Return on Assets (y) terhadap dividen payout ratio (z)

Tabel 4.2 Chow Test $Y$ terhadap $Z$

Redundant Fixed Effects Tests

Equation: Untitled

Test cross-section fixed effects

\begin{tabular}{lrrr}
\hline \hline Effects Test & Statistic & d.f. & Prob. \\
\hline \hline Cross-section F & 2.836311 & $(4,44)$ & 0.0354 \\
Cross-section Chi-square & 11.470055 & 4 & 0.0218 \\
\hline \hline
\end{tabular}

sumber: Output Eviews

Berdasarkan data diatas dapat diketahui bahwa model efek tetap (Fixed Effect) lebih baik dari model pooled least square(common effect), hal tersebut bisa dilihat nilai Prob cross-section $f$ sebesar $0.0354<0.05$ dimana Ho tertolak dan $\mathrm{H} 1$ diterima. 


\section{b. Hausman Test}

Inflasi, Suku bunga, kurs rupiah terhadap Return on Assets

Table 4.3 Hausman Test (X terhadap Y)

Correlated Random Effects - Hausman Test

Equation: Untitled

Test cross-section random effects

\begin{tabular}{lrrr}
\hline \hline Test Summary & $\begin{array}{l}\text { Chi-Sq. } \\
\text { Statistic }\end{array}$ & Chi-Sq. d.f. & Prob. \\
\hline \hline Cross-section random & 0.000000 & 3 & 1.0000 \\
\hline \hline
\end{tabular}

Sumber: output eviews

Hasil output eviews menunjukan bahwa model efek acak lebih unggul dari model efek tetap, hal tersebut bisa dilihat dari nilai random cross-section (prob) sebesar 1 lebih besar dari 0.05 yang berati $\mathrm{H} 1$ ditolak dan Ho diterima.

\section{Return on Asset (Y) terhadap Dividen payout ratio (Z)}

Table 4.4 Hausman test ( $Y$ terhadap z)

\begin{tabular}{|c|c|c|c|c|}
\hline Test Summary & & $\begin{array}{l}\text { Chi-Sa } \\
\text { Statistic }\end{array}$ & chi-sa. a.t. & Prob. \\
\hline Crass-section random & & 0.073079 & 1 & 0.7870 \\
\hline \multicolumn{5}{|c|}{ Cross-section random effects testcomparisons: } \\
\hline Variable & Fixed & Random & Var(Dift,) & Prob. \\
\hline ROA $Y$ & 0.004004 & 0.003550 & 0.000003 & 0.7870 \\
\hline
\end{tabular}

Sumber: output eviews

Dari oleh data menggunakan softwatre eviews dapat diketahui bahwa Random effect Model yaitu model yang terbaik untuk digunakan. Dengan cross-section 0.07 lebih besar dari 0.05 , hal ini menunjukan bahwa Ho diterima dan $\mathrm{H} 1$ ditolak.

\section{c. LM Test}

\section{Inflasi, Suku bunga, kurs rupiah terhadap Return on Assets}

Tabel 4.5 uji LM ( $X$ terhadap Y)

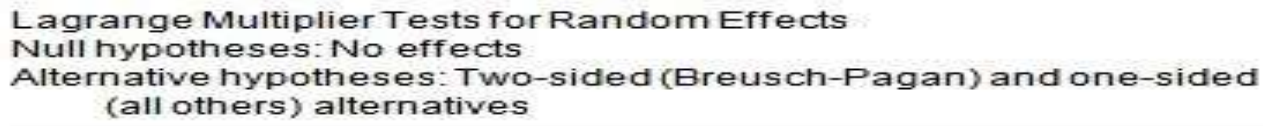

\begin{tabular}{lccc}
\hline \hline & & Test Hypothesis & Both \\
\hline \hline Breusch-Pagan & $\begin{array}{c}9.802501 \\
(0.0017)\end{array}$ & $\begin{array}{l}6.033716 \\
(0.0140)\end{array}$ & $\begin{array}{c}15.83622 \\
(0.0001)\end{array}$ \\
Honda & $\begin{array}{l}3.130895 \\
(0.0009)\end{array}$ & $\begin{array}{l}2.456362 \\
(0.0070)\end{array}$ & $\begin{array}{c}3.950787 \\
(0.0000)\end{array}$ \\
King-Wu & 3.130895 & 2.456362 & 3.967607 \\
& $(0.0009)$ & $(0.0070)$ & $(0.0000)$
\end{tabular}


Output eviews menunjukan hasil Prob Breusch-Pagan adalah 0,0017. Ini berarti bahwa nilai cross-section random kurang dari nilai signifikansinya yaitu 0.05 sehingga $\mathrm{H} 1$ dapat diterima dan $\mathrm{H} 0$ tertolak, artinya adalah Model Random Efek adalah model yang paling tepat

\section{Return on Assets terhadap Dividen payout ratio}

Table 4.6 Uji LM

*

Lagrange Multiplier Tests for Random Effects

Null hypotheses: No effects

Alternative hypotheses: Two-sided (Breusch-Pagan) and one-sided (all others) alternatives

\begin{tabular}{lccc}
\hline \hline & & Test Hypothesis \\
& Cross-section & $\begin{array}{c}\text { Time } \\
\text { Breusch-Pagan }\end{array}$ & Both \\
\hline Honda & $\begin{array}{c}3.002080 \\
(0.0832)\end{array}$ & $\begin{array}{l}0.350100 \\
(0.5541)\end{array}$ & $\begin{array}{l}3.352180 \\
(0.0671)\end{array}$ \\
& 1.732651 & 0.591693 & 1.643559 \\
King-Wu & $(0.0416)$ & $(0.2770)$ & $(0.0501)$ \\
& 1.732651 & 0.591693 & 1.769865 \\
& $(0.0416)$ & $(0.2770)$ & $(0.0384)$
\end{tabular}

Sumber : output eviews

Dari pengujian dengan menggunakan software eviews 9.0 dapat diketahui bahwa Model common efek lebih tepat digunakan, dengan Pob BP sebesar 0.08 lebih besar dari nilai signifikansinya

2. Uji Asumsi klasik

a. Multikolinearitas

Tabel 4.7 Multikolinearitas

\begin{tabular}{|c|c|c|c|}
\hline Ket & Inflasi & Suku Bunga & Kurs \\
\hline Inflasi & 1.000000 & 0.732305 & 0.583036 \\
\hline $\begin{array}{c}\text { Suku } \\
\text { Bunga }\end{array}$ & 0.732305 & 1.000000 & 0.481602 \\
\hline Kurs & 0.583036 & 0.481602 & 1.000000 \\
\hline
\end{tabular}

Pada uji multikolinearitas dengan software eviews dioeroleh nilai matrix korelasi dimana setiap variable independen nilai koefisiennya kurang dari 0.9 hal ini dapat ditarik kesimpulan tidak mengalami masalah multikolinearitas. 
b. Heteroskedastisitas

Tabel 4.8 Uji Glejser Heteroskedasticity Test

F3

Heteroskedasticity Test: Glejser

\begin{tabular}{llll}
\hline \hline F-statistic & 2.166976 & Prob. F $(3,46)$ & 0.1047 \\
Obs ${ }^{\star}$ R-squared & 6.191249 & Prob. Chi-Square(3) & 0.1027 \\
ScaledexplainedSS & 6.029270 & Prob. Chi-Square(3) & 0.1102 \\
\hline \hline
\end{tabular}

Test Equation:

Dependent Variable:ARESID

Method: Least Squares

Date: $11 / 13 / 18$ Time: $23: 19$

Sample: 150

Included observations: 50

\begin{tabular}{crrrr}
\hline \hline Variable & Coefficient & Std. Error & t-Statistic & Prob. \\
\hline \hline C & 4.364505 & 1.558602 & 2.800269 & 0.0074 \\
INFLASI_X1 & 0.271087 & 0.139245 & 1.946842 & 0.0577 \\
SUKU_BUNGA_X2 & -0.546301 & 0.288495 & -1.893625 & 0.0646 \\
KURS_X3 & 0.022034 & 0.028762 & 0.766071 & 0.4475
\end{tabular}

Sumber: output eviews

Untuk mengetahui hasil heteroskeastistas digunakan uji glejser dimana setiap variable independent memiliki sig (Prob) lebih dari 0.05 yang berarti pada model tersebut tidak ditemukan masalah heteroskedastisitas.

3. Pengujian Hipotesis

a. Uji-t

Pengaruh Inflasi terhadap Return on Assets secara parsial

Tabel 4.9 Uji-t X1 terhadap $Y$

Dependent Variable: ROA-Y

Method: Panel EGLS (Cross-section random effects)

Date: $10 / 20 / 18$ Time: $20: 29$

Sample: 20082017

Periods included: 10

Cross-sections included: 5

Total panel (balanced) observations: 50

Swamy and Arora estimator of component variances

\begin{tabular}{|c|c|c|c|c|}
\hline Variable & Coefricient & Std. Error & t-Statistic & Prob. \\
\hline \multirow{4}{*}{ INFLASI_X1 } & 4.531703 & 1.088000 & 4.165168 & 0.0001 \\
\hline & 0.137763 & 0.136088 & 1.012304 & 0.3165 \\
\hline & \multirow{2}{*}{\multicolumn{2}{|c|}{ Efrects Specification }} & & \\
\hline & & & SD. & Rho \\
\hline \multirow{3}{*}{$\begin{array}{l}\text { Cross-section random } \\
\text { Idiosyncratic random }\end{array}$} & & & $\begin{array}{l}1.497271 \\
2.752060\end{array}$ & $\begin{array}{l}0.2284 \\
0.7716\end{array}$ \\
\hline & & & & \\
\hline & \multicolumn{2}{|c|}{ Weighted Statistics } & & \\
\hline \multirow{6}{*}{$\begin{array}{l}\text { R-squared } \\
\text { AdjustedR-squared } \\
\text { S.E, of regression } \\
\text { F-statistic } \\
\text { Prob(F-statistic) }\end{array}$} & \multirow{5}{*}{$\begin{array}{l}0.020903 \\
0.000505 \\
2.752060 \\
1.024760 \\
0.316468\end{array}$} & \multirow{5}{*}{\multicolumn{2}{|c|}{$\begin{array}{l}\text { Mean dependent var } \\
\text { S.D. dependent var } \\
\text { Sum squaredresid } \\
\text { Durbin-Watson stat }\end{array}$}} & 2.665999 \\
\hline & & & & 2.752755 \\
\hline & & & & 363.5441 \\
\hline & & & & 0.910592 \\
\hline & & & & \\
\hline & \multicolumn{3}{|c|}{ Unweighted Statistics } & \\
\hline \multirow{2}{*}{$\begin{array}{l}\text { R-squared } \\
\text { Sum squared resid }\end{array}$} & 0.016837 & Mean depen & t var & 5.305240 \\
\hline & 453.2169 & Durbin-Wats & tat & 0.730424 \\
\hline
\end{tabular}

Sumber: output eviews 9

Jurnal SEKURITAS (Saham, Ekonomi, Keuangan dan Investasi ), Vol.3, No.3, Mei 2020. 
Berdasarkan pengujian tersebut dapat diketahui bahwa sig a prob 0.316 lebih besar dari nilai signifikansinya yaitu 0.05 , dan t-hitung 1.01234 sedangkan t-tabel pada tingkat sig $\alpha=5 \%$ serta $d f=(n-k)=50-3=47$. maka diperoleh t-table sebesar 2.01147 . hal ini berarti $t$ hitung $<$ t-tabel dimana $1.01234<2.01147$. secara statistic dapat disimpulkan bahwa $\mathrm{H} 1$ diterima sementara $\mathrm{H} 0$ ditolak, artinya inflasi $\left(\mathrm{X}_{1}\right)$ tidak berpengaruh terhadap ROA $(\mathrm{Y})$ secara signifikan.

\section{Pengaruh Variabel $X_{2}$ (Suku bunga) Terhadap Variabel $Y(R O A)$ secara parsial}

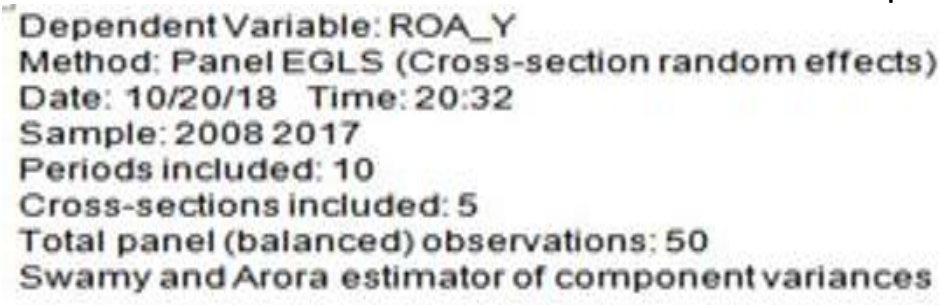

\begin{tabular}{crrrr}
\hline \multicolumn{1}{c}{ Variable } & Coefficient & Std. Error & t-Statistic & Prob. \\
\hline SUKU_BUNGA_X2 & $\begin{array}{r}6.010355 \\
-0.128373\end{array}$ & $\begin{array}{l}2.227656 \\
0.309728\end{array}$ & $\begin{array}{r}2.698063 \\
-0.414468\end{array}$ & $\begin{array}{l}0.0096 \\
\end{array}$ \\
& Effects Specification & & \\
\hline & & & S.D. & Rho \\
\hline $\begin{array}{l}\text { Cross-section random } \\
\text { Idiosyncratic random }\end{array}$ & & & 1.473893 & 0.2167 \\
\hline
\end{tabular}

Weighted Statistics

\begin{tabular}{lrll}
\hline R-squared & 0.003566 & Mean dependent var & 2.650695 \\
AdjustedR-squared & -0.017193 & S.D. dependent var & 2.778786 \\
S.E. of regression & 2.802572 & Sum squared resid & 377.0117 \\
F-statistic & 0.171784 & Durbin-Watson stat & 0.916811 \\
Prob(F-statistic) & 0.680378 & & \\
\hline
\end{tabular}

Unweighted Statistics

\begin{tabular}{llll}
\hline R-squared & 0.002900 & Mean dependent var & 5.143840 \\
Sum squared resid & 463.9061 & Durbin-Watson stat & 0.745083 \\
\hline
\end{tabular}

Sumber:output eviews

Berdasarkan pengujian tersebut dapat diketahui bahwa sig a prob 0.68 lebih besar dari standar signifikansinya yaitu 0.05 , dan t-hitung -0.414468 sedangkan t-tabel pada tingkat sig $\alpha=5 \%$ serta $d f=(n-k)=50-3=47$. maka diperoleh $t$-table sebesar 2.01147. hal ini berarti t hitung < t-tabel dimana $-0.414<2.01147$. secara statistic dapat disimpulkan bahwa $\mathrm{H} 1$ diterima sementara $\mathrm{H} 0$ ditolak, artinya Suku Bunga $\left(\mathrm{X}_{2}\right)$ tidak berpengaruh terhadap ROA (Y) secara signifikan. 


\section{Pengaruh Variabel $X_{3}$ (Kurs Rupiah) terhadap Variabel Y (ROA)}

\section{Tabel 4.12 Kurs Terhadap ROA}

Dependent Variable: ROA_r

Method: Panel EGLS (Cross-section random effects)

Date: 10/20/18 Time: 20:35

Sample: 20082017

Periods included: 10

Cross-sections included: 5

Total panel (balanced) observations: 50

Swamy and Arora estimator of component variances

\begin{tabular}{|c|c|c|c|c|}
\hline Variable & Coefficient & Std. Error & t-Statistic & Prob. \\
\hline \multirow{4}{*}{$\stackrel{\text { C }}{\text { KURS_X3 }}$} & 4.998730 & 0.788582 & 6.338883 & 0.0000 \\
\hline & 0.072169 & 0.034940 & 2.065509 & 0.0443 \\
\hline & \multicolumn{2}{|c|}{ Effects Specification } & & \\
\hline & & & & \\
\hline \multirow{3}{*}{$\begin{array}{l}\text { Cross-section random } \\
\text { diosyncratic random }\end{array}$} & & & 1.514162 & 0.2450 \\
\hline & & & 2.658040 & 0.7550 \\
\hline & \multicolumn{2}{|c|}{ Weighted Statistics } & & \\
\hline \multirow{6}{*}{$\begin{array}{l}\text { R-squared } \\
\text { AdjustedR-squared } \\
\text { S.E. of regression } \\
\text { F-statistic } \\
\text { Prob(F-statistic) }\end{array}$} & 0.081627 & \multirow{5}{*}{\multicolumn{2}{|c|}{$\begin{array}{l}\text { Mean dependent var } \\
\text { S.D. dependent var } \\
\text { Sum squared resid } \\
\text { Durbin-Watson stat }\end{array}$}} & 2.574919 \\
\hline & 0.062494 & & & 2.745203 \\
\hline & 2.658040 & & & 339.1284 \\
\hline & 4.266328 & & & 1.261312 \\
\hline & 0.044297 & & & \\
\hline & \multicolumn{3}{|c|}{ Unweighted Statistics } & \\
\hline \multirow{2}{*}{$\begin{array}{l}\text { R-squared } \\
\text { Sum squared resid }\end{array}$} & 0.065388 & \multirow{2}{*}{\multicolumn{2}{|c|}{$\begin{array}{l}\text { Mean dependent var } \\
\text { Durbin-Watson stat }\end{array}$}} & 5.305240 \\
\hline & 430.8359 & & & 0.992830 \\
\hline
\end{tabular}

Sumber: output eviews

Berdasarkan pengujian tersebut dapat diketahui bahwa sig a prob 0.04 lebih kecil dari 0.05 , dan t-hitung 2.0655 sedangkan t-tabel pada tingkat sig $\alpha=5 \%$ serta $\mathrm{df}=(\mathrm{n}$ $k)=50-3=47$. maka diperoleh $\mathrm{t}$-table sebesar 2.01147. hal ini berarti t hitung $>\mathrm{t}$-tabel dimana $2.0655>2.01147$. secara statistic dapat disimpulkan bahwa H1 diterima sementara $\mathrm{HO}$ ditolak, artinya kurs berpengaruh terhadap $\mathrm{ROA}(\mathrm{Y})$ secara signifikan

\section{Pengaruh $\mathrm{Y}$ terhadap $\mathrm{Z}$}

Dependent Variable:DPR_Z

Tabel 4.13 ROA terhadap DPR

Method: Panel Least Squares

Date: 10/20/18 Time: 20:41

Sample: 20082017

Periods included: 10

Cross-sections included: 5

Total panel (balanced) observations: 50

\begin{tabular}{lrlrr}
\hline \hline \multicolumn{1}{c}{ Variable } & Coefficient & Std. Error & t-Statistic & Prob. \\
\hline \hline ROA_Y & 0.151977 & 0.032238 & 4.714237 & 0.0000 \\
\hline R-squared & 0.002639 & 0.005274 & 0.500474 & 0.6190 \\
AdjustedR-squared & 0.005191 & Mean dependent var & 0.165980 \\
S.E. of regression & -0.015534 & S.D. dependent var & 0.112364 \\
Sumsquared resid & 0.113233 & Akaike info criterion & -1.479558 \\
Loglikelihood & 0.615443 & Schwarz criterion & -1.403077 \\
F-statistic & 38.98895 & Hannan-Quinn criter. & -1.450434 \\
Prob(F-statistic) & 0.250474 & Durbin-Watson stat & 1.067220 \\
\hline \hline
\end{tabular}

Sumber: output eviews 
Berdasarkan pengujian tersebut dapat diketahui bahwa sig a prob 0.619 lebih besar dari standar signifikansinya yaitu 0.05 , dan t-hitung 0.500474 sedangkan t-tabel pada tingkat sig $\alpha=5 \%$ serta $d f=(n-k)=50-1=49$. maka diperoleh $t$-table sebesar 2.00958 . hal ini berarti $t$ hitung $<\mathrm{t}$-tabel dimana $0.500474<2.01147$. secara statistic dapat disimpulkan bahwa $\mathrm{H} 1$ diterima sementara $\mathrm{H} 0$-nya ditolak, artinya Variabel Return on Asset tidak berpengaruh terhadap Dividen Payout Ratio secara signifikan.

b. Uji-F (simultan)

Pengaruh inflasi, suku bunga dan kurs terhadap Return on Asset secara bersamasama

Tabel 4.14

X1, X2, X3 Terhadap Y secara Simultan

\begin{tabular}{|c|c|c|c|c|}
\hline \multicolumn{5}{|c|}{$\begin{array}{l}\text { Dependent Variable: ROA } \\
\text { Method: PanelEGLS (Cross-section random effects) } \\
\text { Date: 10/2O/18 Time: } 20: 45 \\
\text { Sample: } 20082017 \\
\text { Periodsinduded: } 10 \\
\text { Cross-sections included: } 5 \\
\text { Total panel (balanced) observations: } 50 \\
\text { Swamy and Arora estimator of component variances }\end{array}$} \\
\hline Variable & Coefficient & Std. Error & t-Statistic & Prob. \\
\hline & 8.176544 & 2.438120 & 3.363627 & 0.0016 \\
\hline \multirow{3}{*}{$\begin{array}{l}\text { INFLASI_X1 } \\
\text { SUKU_BUNGA-X2 } \\
\text { KURS_X3 }\end{array}$} & 0.164382 & 0.209261 & 0.737784 & 0.4644 \\
\hline & -0.605997 & 0.433538 & -1.397794 & 0.1689 \\
\hline & 0.082956 & 0.043222 & 1.919290 & 0.0612 \\
\hline \multicolumn{5}{|c|}{ Effects Specification } \\
\hline & & & S.D. & Rho \\
\hline Cross-section random & & & 1.514113 & 0.2450 \\
\hline Idiosyncratic random & & & 2.658319 & 0.7550 \\
\hline \multicolumn{5}{|c|}{ Weighted Statistics } \\
\hline R-squared & 0.119722 & \multirow{5}{*}{\multicolumn{2}{|c|}{$\begin{array}{l}\text { Mean dependent var } \\
\text { S.D. dependent var } \\
\text { Sum squared resid } \\
\text { Durbin-Watsonstat }\end{array}$}} & 2.575189 \\
\hline Adjusted R-squared & 0.062312 & & & 2.745225 \\
\hline S.E. of regression & 2.658319 & & & 325.0663 \\
\hline F-statistic & 2.086398 & & & 1.272865 \\
\hline Prob(F-statistic) & 0.116151 & & & \\
\hline \multicolumn{5}{|c|}{ Unweighted Statistics } \\
\hline $\begin{array}{l}\text { R-s quared } \\
\text { Sum squared resid }\end{array}$ & $\begin{array}{l}0.095906 \\
416.7678\end{array}$ & $\begin{array}{l}\text { Mean depen } \\
\text { Durbin-Wats }\end{array}$ & $\begin{array}{l}\text { nt var } \\
\text { stat }\end{array}$ & $\begin{array}{l}5.305240 \\
0.992796\end{array}$ \\
\hline
\end{tabular}

Sumber: output Eviews

Nilai probabilitas (F-statistic) sebesar $0.115151>$ tingkat signifikansi 0,05, Kemudian nilai F-hitung (F-statistic) sebesar 2.085398. Nilai F-tabel dengan $\alpha=5 \%(0,05)$ dan df $(k-1)=(3-1)=2$ dan df2 $(n-k)=50-3=47$ menunjukkan angka 3,20. Sehingga $f-$ hitungnya (2.085392) < nilai F-tabelnya $(3,20)$, jadi $\mathrm{H} 0$-nya diterima dan $\mathrm{H} 1$ ditolak variabel artinya bahwa Inflasi (X1), Suku Bunga (X2), dan Kurs Rupiah (X3) tidak berpengaruh signifikan terhadap Return on Asset $(Y)$ secara simultan. Model Persamaan Regresi pada Variabel $X 1$, $X 2$, dan $X 3$ terhadap $Y$ adalah $Y=8.176544+0.154382 X 1-0.605997 X 2+0.082956 \times 3$ 


\section{E. KESIMPULAN}

\section{a. Kesimpulan}

Bersadarakan pengujian dan analisis yang telah dilakukan diatas kesimpulannya adalah sebagai berikut:

1. Diketahui bahwa tidak terdapat pengaruh yang signifikan antara variable Independennya yaitu Inflasi terhadap Variabel Dependennya yaitu Return on Asset. Dimana berdasarkan pengujian dengan eviews 9 diperoleh nilai Probabilitasnya lebih besar dari konstanta $(0.3165>0,05)$, selain itu nilai thitungnya adalah 1.01234, sedangkan t-tabelnya pada $d f=(n-k)=50-3=47$, $(0,05 ; 47)=2.01147$. dengan nilai $t$-tabel tersebut maka $t$ hitung $(1.01234)$ kurang dari t-tabel (2.01147), secara statistik disimpulkan bahwa HO ditolak sedangkan $\mathrm{H} 1$ diterima.

2. Diketahui bahwa tidak terdapat pengaruh yang signifikan antara variable Suku Bunga (X2) terhadap Variabel Dependennya yaitu Return on Asset (Y). Dimana berdasarkan pengujian dengan eviews 9 diperoleh nilai Probabilitasnya lebih besar dari konstanta dimana $(0.68>0,05)$, selain itu nilai t-hitungnya adalah 0.414468 , sedangkan t-tabelnya pada $\mathrm{df}=(\mathrm{n}-\mathrm{k})=50-3=47,(0,05 ; 47)=2.01147$. dengan nilai $\mathrm{t}$-tabel tersebut, maka $\mathrm{t}$ hitung $(-0.414468)$ kurang dari t-tabel (2.01147), secara statistik disimpulkan bahwa $\mathrm{H} 0$ ditolak sedangkan $\mathrm{H} 1$ diterima. Yang berarti suku Bunga tingkat signifikasinya tidak berpengaruh pada ROA

3. Kurs rupiah sebagai variable bebas berpengaruh significant terhadap dependent variable-nya yaitu Return on Asset. Dimana berdasarkan pengujian dengan eviews 9 diperoleh nilai Probabilitasnya kurang dari konstanta $(0.04<0,05)$, selain itu nilai $t$-hitungnya adalah 2.065509 , sedangkan $\mathrm{t}$-tabelnya pada $\mathrm{df}=(\mathrm{n}-\mathrm{k})=$ $50-3=47,(0,05 ; 47)=2.01147$. dengan nilai t-tabel tersebut maka t-hitung $>t$-tabel $(2.065509>2.01147)$, secara statistik disimpulkan bahwa HO diterima sedangkan H1 ditolak. Yang berarti Bahwa Kurs Rupiah berdasarkan tingkat signifikansinya berpengaruh pada ROA

4. Secara simultan dapat diketahui bahwa variabel inflasi, suku bunga dan kurs rupiah tidak terdapat pengaruh yang signifikan terhadap variabel dependennya yaitu Return on Asset. Adapun prob a F-Statistik nilainya 0.11515 lebih besar dari Konstanta $(0.11515>0.05)$. kemudian nilai F Hitung (F-Statistic) sebesar 2.08539. adapun nilai f-table pada $\alpha=0.05$ dapat diketahui $\mathrm{df}=(\mathrm{K}-\mathrm{I})=3-1=2$ sementara df $2(n-k)=50-3=47$, menunjukan angka 3.20 artinya $f$-statistic $<$-table $(2.08539<$ 3.20) jadi Ho diterima dan $\mathrm{H} 1$ ditolak.

5. DPR ( $Y$ ) tidak dipengaruhi secara signifikan oleh ROA, hasil t-hitung ROA menunjukan 0.500474 , dengan perhitungan t-tabel diperoleh sebesar 2.0147 sehingga t-hitung kurang dari t-tabel $(0.500474<2.0147)$ secara statistik disimpulkan bahwa Ho ditolak dan $\mathrm{H} 1$ diterima.

\section{b. Saran}

1. Bagi Perusahaan dan investor dalam penelitan ini dapat diketahui bahwa kurs memiliki pengaruh yang signifikan terhadap Profitabilitas, oleh karena itu investor dan perusahaan wajib mencermati kondisi makro ekonomi dan mengantisipasi kenaikan dan penurunan kurs rupiah, kenaikan kurs tentunya akan membat bahan atau material impor serta beban hutang luar negeri menjadi besar, tentunya ini akan memberikan efek bagi kinerja keuangan perusahaan khususnya terhadap profitabilitasnya. 
2. Bagi Peneliti hendaknya melakukan penelitian dengan menggunakan unit analisis yang berbeda dan dengan sample yang lebih banyak agar informasi dan hasil penelitian diperoleh secara maksimal.

\section{DAFTAR PUSTAKA}

Bank Indonesia. (2016). BI Rate. Metadata. https://www.bi.go.id/id/statistik/metadata/seki/Documents/8_Suku_Bunga_Indo_DPM SEKI_2016 (Indonesia) new.pdf

Darsono, \& Ashari. (2009). Aplikasi Analisis Laporan Keuangan. Liberty.

Kadim, A., \& Sunardi, N. (2019, May). Eviews Analysis; Determinan Tourism, Restaurant and Hotel Company's Soundness and Performance. In Proceeding Interuniversity Forum for Strengthening Academic Competency (Vol. 1, No. 1, pp. 332-340).

Kunawangsih, P. T., \& Pracoyo, A. (2007). Aspek Dasar Ekonomi Makro Di Indonesia. Grasindo Riduwan. (2014). Metode dan Teknik Menyusun Tesis (Cetakan Ke). ALFABETA.

Sadono, S. (2004). Macroeconomic Introduction Theory. In Third edition, PT RajaGrafindo Persada, Jakarta.

Sodiq, A. (2016). Pengaruh Variabel Makro Ekonomi Terhadap Profitabilitas Bank Syariah Di Indonesia Periode 2009 - 2014. BISNIS : Jurnal Bisnis Dan Manajemen Islam, 3(2), 343. https://doi.org/10.21043/bisnis.v3i2.1508

Sunardi, N. (2017). Pengaruh Profitabilitas, Firm Size, Risiko Bisnis, Asset Growth, Leverage, Kebijakan Dividen Terhadap Institutional Ownership (Perusahaan Property \& Real Estate yang terdaftar di Bursa Efek Indonesia Tahun 2011-2014). INOVASI, 2(2).

Sunardi, N. (2018). Kinerja Perusahan Pendekatan Du Pont System Terhadap Harga Dan Return Saham (Perusahaan yang tergabung dalam Industri Real Estate dan Properti yang terdaftar di Bursa Efek Indonesia Tahun 2011-2017). JIMF (Jurnal IImiah Manajemen Forkamma), 1(3).

Sutrisno. (2013). Manajemen Keuangan Teori Konsep dan Aplikasi. In Manajemen Keuangan Teori Konsep dan Aplikasi.

Tri Basuki, A., \& Yuliadi, I. (2015). Electronic Data Procesing (SPSS 15 dan Eviews 7) (Edisi Revi). Danisa Media.

Wade, L. (1961). Electronic data processing. In Archives of Environmental Health (Vol. 3, Issue 5). https://doi.org/10.1080/00039896.1961.10663066 